\title{
MACROECONOMICS DETERMINANTS OF EXTERNAL DEBT IN MALAYSIA
}

\author{
EVAN LAU, ALVINA SYN-YEE LEE, MOHAMMAD AFFENDY ARIP
}

\begin{abstract}
:
The management of debt has always been one of the central concerns in the small open economy like Malaysia. This study seeks to re-examine whether the macroeconomic indicators contributed to the external debt in Malaysia. Utilizing Malaysia data from 1970 to 2013, the results indicate the existence of short run causality linkages between the external debt and the macroeconomic indicators. Further dynamic analysis indicates that real interest rate (RIR) to be the most exogenous variable beyond the sample for the next 50 years. This implies that policymakers could focus on the monetary variables in assisting and managing external debt level in the long run. Malaysia should develop a debt governance program for pursuit of debt-targeting policies or rules to enhance sound public finance systems which is crucial for Malaysia to achieve solvency in external debt positions in the near future.
\end{abstract}

\section{Keywords:}

External Debt; Macroeconomic Indicators; Malaysia.

JEL Classification: F34, C22

\section{Authors:}

EVAN LAU, Universiti Malaysia Sarawak, Malaysia, Email: Iphevan@feb.unimas.my ALVINA SYN-YEE LEE, Universiti Malaysia Sarawak, Malaysia, Email: alvinalsy@gmail.com MOHAMMAD AFFENDY ARIP, Universiti Malaysia Sarawak, Malaysia, Email: amaffendy@feb.unimas.my

\section{Citation:}

EVAN LAU, ALVINA SYN-YEE LEE, MOHAMMAD AFFENDY ARIP (2015). MACROECONOMICS DETERMINANTS OF EXTERNAL DEBT IN MALAYSIA. International Journal of Economic Sciences, Vol. IV(4), pp. 14-26., 10.20472/ES.2015.4.4.002 


\section{Introduction}

The sovereign debt crisis which strikes the European countries has threatened the global economy as a whole. Economic activity in the euro area remained weak amid austerity measures and ongoing sovereign debt concerns. In Asia, growth of several economies moderated in the second quarter of 2013, as the prolonged weakness in the external environment had begun to affect domestic economic activity, particularly in the more open economies. The great uncertainty resulting from sovereign risk faced by these countries are mainly attributed to excessive debt and budget deficit levels maintained by governments (Cheong et al., 2011).

Among the popular measure to mitigate were the fiscal stimuli to jump-start the economy but at the same time it brings additional pressure to the debt position around the globe. Zhang and Zhang (2011) stated that while fiscal stimulus are important for short-term measure, it is likely to be less effective from a medium-term to long-term perspective which may generate some side effects due to the concerns over fiscal sustainability and inflationary pressure. Evidently, many countries around the world have accumulated large debt in the aftermath of the global financial crisis (Baldacci et al., 2010). As reported by Cottarelli and Schaechter (2010), developed countries external debt levels were projected to rise-as percentage of GDP_from an average of about $73 \%$ in 2007 to about $108 \%$ in 2014 . While the trajectory to recovery varies widely across regions, additional threat to the restoration of economic growth is worsening especially on the debt crisis in Europe.

Looking at the literature, external vulnerability and insolvency of a country took place after the foreign debt crisis in the 1980's (Cline, 1984; McFadden et al., 1985). Most of these studies attempt to analyze the determinants of debt servicing difficulties in the first wave of debt crisis. Ajayi (1991) stressed that the causes of the debt accumulation could be categorized into the domestic factors and the external factors where the external factors do affect crucially on what happens domestically. Qu (2010) on other hand defines external debt as the capital borrowed from an external source, where the government gain the loans by issuing government bonds, securities and bills, in which he found that the accumulation of external debts in developing countries are mainly caused by the irrational debt structure, improper use of debt and deteriorating situation in foreign trade that causes the sharp cut off of export income. Loser (2004) stated that among the external debt indicators were the net international reserves, real effective exchange rate, inflation, output growth, export and import behaviour, terms of trade, monetary indicators, interest rates and fiscal deficit and credit to the public sector.

Further, Sabahat and Butt (2008) discussed the external debt and examine the impact of trade liberalization policies in Pakistan. Their results suggest a significant long run positive association between external debt and trade liberalization where trade liberalization is the stimulator of external debt accumulation. Awan, Asghar and 
Rehman (2011) analyse the relationship between external debt, exchange rate, fiscal deficit and terms of trade where they found significant long run relationship between these variables. On Malaysian case, Loganathan, et al. (2010) indicated that the macroeconomics performance on the burden of external debt in Malaysia is deems to be sustainable. By utilizing Autoregressive Distributed Lag (ARDL) for the period 1991 to 2009, Daud et al. (2013) found that the accumulation of external debt is associated with an increase in Malaysia's economic growth up to an optimal level and an additional increase of external indebtedness beyond the level has inversely contributed to the Malaysian economy. Choong, Lau, Liew, and Puah (2010) examined the effect of different types of debts on the economic growth in Malaysia during the period from 1970 to 2006 . The findings suggest that all components of debts have a negative effect on long run economic growth. The Granger causality test reveals the existence of a short-run causality linkage between all debt measures and economic growth in the short-run. Pyeman, Noor, Mohamad and Yahya (2014) studied the determinants that contributing to the external debt in Malaysia. The empirical findings show that gross domestic product, export and foreign direct investment are important indicators affecting the external debt in Malaysia from 1972 to 2012.

This open up an important question of whether, a small open economy like Malaysia would be immune from the negative impact? Could we experience the sovereign default in the near future? What are the macroeconomic indicators involved? According to Reinhart and Rogoff (2009, pp. 23 - 24), debt thresholds of emerging market in the time of default were averaging from $41 \%$ to $60 \%$ of the GNP. Although the debt level in Malaysia remains manageable where the total external debt of $29.8 \%$ in June 2013 (BNM, 2013), we should be cautious on the increasing trend of our external debt. Furthermore, between 2000 and 2009, Malaysia's federal deficits were the highest in ASEAN countries (Narayanan, 2012, pp. 133). Malaysia leading challenge today is to reduce the inflation rate, poverty level and external debt as part of nation's agenda towards sustainable economic growth (Loganathan, Sukemi and Sanusi, 2010).

Owing to the background above, this paper seeks to re-examine the macroeconomics determinant of external debt in Malaysia for the time period of 1970 to 2013. This is in line with the nation's transformation programs for propelling Malaysia into a high income developed nation. ${ }^{1}$ The rest of the paper is organized as follows. Section 2 explains the methodology employed while section 3 reports the empirical results. Lastly, section 4 conclude the overall findings.

\footnotetext{
1 These among others were the Economics Transformation Program (ETP) and the Government Transformation Programs (GTP) of which smart partnership exists between the private and public sectors. It is anchored on a clear implementation roadmap with strong performance management and transparency.
} 


\section{Methodology, Empirical Model and Data Description}

\subsection{Unit root tests}

In carrying out the cointegration analysis, unit root tests are employed first. In this study, Dickey and Fuller (1979, ADF) and Kwiatkowski, Phillips, Schmidt and Shin (1992, KPSS) tests are implemented. The ADF test the null of nonstationarity whereas the KPSS tests the null of stationarity.

\subsection{Cointegration test}

After prompting by the existence of unit roots in the variables, an estimation on multivariate cointegration technique which developed by Johansen and Juselius (1990, $\mathrm{JJ}$ ) is adopted. Cointegration technique investigates the existence of the long-run cointegrating relation between two or more variables. JJ have suggested two alternatives to test the long-run relationship between the variables, which are trace statistics and maximal eigenvalue. As it become norm in empirical time series econometrics estimation, detail of the $\mathrm{JJ}$ test were not presented here but interested reader could refer to the original article for detail implementation.

\subsection{Granger Causality test}

Engle and Granger (1987, EG) exhibited that if the cointegration is detected, there always exists a corresponding error-correction representation which implies that changes in the dependent variable are a function of the level of disequilibrium in the cointegrating relationship which captured by the error-correction term (ECT), as well as changes in other explanatory variables. Therefore, for cointegrated model, we will test for the Granger causality in VECM environment. The existence of a cointegrated relationship in the long run indicates that the residuals from the cointegration equation can be used as ECT as follows:

$$
\begin{aligned}
& \Delta E D_{t}=\delta_{0}+\sum_{i=1}^{m} \alpha_{1} \Delta E D_{t-1}+\sum_{i=1}^{n} \alpha_{2} \Delta G D P_{t-1}+\sum_{i=1}^{o} \alpha_{3} \Delta R I R_{t-1}+\sum_{i=1}^{p} \alpha_{4} \Delta C P I_{t-1}+\sum_{i=1}^{q} \alpha_{5} \Delta M 2_{t-1}+\mu_{1} E C T_{t-1}+\varepsilon_{1} \\
& \Delta G D P_{t}=\omega_{0}+\sum_{i=1}^{m} \beta_{1} \Delta G D P_{t-1}+\sum_{i=1}^{n} \beta_{2} \Delta E D_{t-1}+\sum_{i=1}^{o} \beta_{3} \Delta R I R_{t-1}+\sum_{i=1}^{p} \beta_{4} \Delta C P I_{t-1}+\sum_{i=1}^{q} \beta_{5} \Delta M 2_{t-1}+\mu_{2} E C T_{t-1}+\varepsilon_{2} \\
& \Delta R I R_{t}=\theta_{0}+\sum_{i=1}^{m} \phi_{1} \Delta R I R_{t-1}+\sum_{i=1}^{n} \phi_{2} \Delta E D_{t-1}+\sum_{i=1}^{o} \phi_{3} \Delta G D P_{t-1}+\sum_{i=1}^{p} \phi_{4} \Delta C P I_{t-1}+\sum_{i=1}^{q} \phi_{5} \Delta M 2_{t-1}+\mu_{3} E C T_{t-1}+\varepsilon_{3} \\
& \Delta C P I_{t}=\varphi_{0}+\sum_{i=1}^{m} \gamma_{1} \Delta C P I_{t-1}+\sum_{i=1}^{n} \gamma_{2} \Delta E D_{t-1}+\sum_{i=1}^{o} \gamma_{3} \Delta G D P_{t-1}+\sum_{i=1}^{p} \gamma_{4} \Delta R I R_{t-1}+\sum_{i=1}^{q} \gamma_{5} \Delta M 2_{t-1}+\mu_{4} E C T_{t-1}+\varepsilon_{4} \\
& \Delta M 2_{t}=\sigma_{0}+\sum_{i=1}^{m} \partial_{1} \Delta M 2_{t-1}+\sum_{i=1}^{n} \partial_{2} \Delta E D_{t-1}+\sum_{i=1}^{o} \partial_{3} \Delta G D P_{t-1}+\sum_{i=1}^{p} \partial_{4} \Delta R I R_{t-1}+\sum_{i=1}^{q} \partial_{5} \Delta C P I_{t-1}+\mu_{5} E C T_{t-1}+\varepsilon_{5}
\end{aligned}
$$


Where, $\Delta$ is the lag operator, $\delta_{0}, \omega_{0}, \theta_{0}, \varphi_{0}, \sigma_{0}, \alpha$ 's, $\beta$ 's, $\emptyset$ 's, $\varphi$ 's and $\sigma$ 's are the estimated coefficients, $m, n, o, p$ and $q$ are the optimal lags of external debt $(E D)$, gross domestic product (GDP), real interest rate $(R I R)$, inflation rate $(C P I)$ and quasi money to gross international reserves (M2) series, $\varepsilon$ 's are the serially uncorrelated random error terms while $\mu_{1}, \mu_{2}, \mu_{3}, \mu_{4}$ and $\mu_{5}$ measure the single period response of a departure from equilibrium of the dependent variable.

\subsection{Data Description and Empirical Model}

Time series data spanning from 1970 to 2013 are utilized in this study². The sources of data from this study are obtained from International Monetary Fund and World Bank. This paper concentrates on the macroeconomics determinants of the external debt $(E D)$ in Malaysia. The following explanatory variables are used for this purpose: Gross domestic product (current GDP, USD), real interest rate $(R I R)$, Inflation (measured by the percentage change in the $\mathrm{CPI}$ ), and money and quasi money (M2) to total reserves ratio (M2). Prior to the analysis, all variables are transformed into logarithm form. Malaysia has faced several unstable economic scenarios during the last two decades especially during the Asian Financial Crisis. Hence, for estimation purpose, we modified the model from Zeaiter (2009) which is specified as following ${ }^{3}$ :

$$
E D_{t}=\beta_{0}+\beta_{1} G D P_{t}+\beta_{2} R I R_{t}+\beta_{3} C P I_{t}+\beta_{4} M 2_{t}+\varepsilon_{t}
$$

\section{Empirical Results}

\subsection{Unit root and Cointegration results}

The results of ADF and KPSS tests suggest that all variables are nonstationary at the level form but stationary after first differencing $l(1)^{4}$. Results are not presented here but made available upon request. The null hypothesis of no cointegrating vector $(r=0)$ is rejected at 5 percent significance level for both the trace and maximum eigenvalue test (see Table 1). This reveals that there is a single cointegrating vector in a stable long run relationship between the external debt and the selected macroeconomic indicators for Malaysia. We noted that both the trace and the maximum eigenvalue

\footnotetext{
${ }^{2}$ We are grateful to the anonymous referees for suggesting this point. The sample period is extended from 42 observations (1970-2011) to 44 observations (1970-2013) and the entire empirical analysis has been re-estimated.

${ }^{3}$ The study by Zeaiter (2009) has examined the factors that influence the external debt default in developing countries. Based on the study from Zeaiter, the explanatory variables used are: the ratio of current account balance to exports, credit to the private sector as a percentage of GDP, the ratio of money and quasi money to gross international reserves, inflation, real exchange rate, GNP per capita, real interest rate, the ratio of total external debt to export, variability of GDP growth and political risk index. Nevertheless, due to the data set availability issue, the choice of these macroeconomics variables in this paper is lessen to four variables.

4 We also test for the unit root during 1970-2011 in the earlier version of this paper. Overwhelmingly, the evidence also supports the I(1) properties of all the series.
} 
tests led to the same conclusion-the presence of one cointegrating vector. Rejecting the null hypothesis of no cointegration implies that the five variables do not drift apart and share at least a common stochastic trend in the long run.

Table 1: Results of Johansen and Juselius Cointegration Test

\begin{tabular}{cccccc}
\hline \multirow{2}{*}{ Null } & \multirow{2}{*}{ Alternative } & \multicolumn{4}{c}{$\mathbf{k = 2 , \mathbf { r } = \mathbf { 1 }}$} \\
\cline { 3 - 6 } & & Max-Eigen Value & \multicolumn{2}{c}{ Trace } \\
& & Statistic & $\mathbf{9 5 \%} \mathbf{C V}$ & Statistic & $\mathbf{9 5 \%} \mathbf{~ C V}$ \\
\hline$r=0$ & $r=1$ & $45.526^{\star *}$ & 30.440 & $84.639^{\star *}$ & 60.061 \\
$r \leq 1$ & $r=2$ & 17.535 & 24.159 & 39.114 & 40.175 \\
$r \leq 2$ & $r=3$ & 11.933 & 17.797 & 21.578 & 24.276 \\
$r \leq 3$ & $r=4$ & 9.597 & 11.225 & 9.646 & 12.321 \\
$r \leq 4$ & $r=5$ & 0.049 & 4.130 & 0.049 & 4.130 \\
\hline
\end{tabular}

Notes: Asterisk $\left(^{* *}\right)$ denotes statistically significant at 5percent significance level. The $k$ indicates the lag length and $r$ indicates the number of cointegrating vector(s).

\subsection{Causality Results}

The causality relationship between external debt and the macroeconomic indicators are shown in Table 2. The M2 equation is the only one in the system where the ECT is statistically significant. This suggests that M2 solely bears the brunt of short run adjustment to bring about the long run equilibrium in Malaysia, which is in line with the cointegrating relationship found earlier. This indicates that M2 acts as the initial receptor of any exogenous shocks that disturb the equilibrium system. The $t$-statistic on the lagged residual is also statistically significant and negative supporting the $\mathrm{JJ}$ results reported earlier. The coefficient of the ECT determines the speed of the temporal adjustment to the long run equilibrium in the system which is denoted by the cointegration relationship. In this manner the adjustment is about 18.1 percent annually, which will take around 5.5 years to adjust to the long run equilibrium due to short run shocks. 
Table 2: Granger Causality Results

\begin{tabular}{|c|c|c|c|c|c|c|c|}
\hline \multirow{2}{*}{$\begin{array}{c}\text { Depende } \\
\text { nt } \\
\text { variables }\end{array}$} & $\Delta \mathrm{ED}$ & $\Delta$ GDP & $\Delta \mathbf{R I R}$ & $\Delta \mathrm{CPI}$ & $\Delta \mathbf{M} 2$ & \multirow{2}{*}{$\begin{array}{c}\text { EC } \\
\text { Coefficie } \\
\text { nt }\end{array}$} & \\
\hline & \multicolumn{5}{|c|}{$\mathrm{X}^{2}$ statistics } & & t-ratio \\
\hline$\Delta \mathrm{ED}$ & - & $\begin{array}{c}4.328 \\
(0.1149)\end{array}$ & $\begin{array}{c}2.117 \\
(0.3470)\end{array}$ & $\begin{array}{c}0.933 \\
(0.627 \\
0)\end{array}$ & $\begin{array}{c}6.513 \\
(0.0385) \\
\star \star\end{array}$ & -0.014 & -0.385 \\
\hline$\Delta \mathrm{GDP}$ & $\begin{array}{c}3.184 \\
(0.2035)\end{array}$ & - & $\begin{array}{c}12.830 \\
\underset{* *}{(0.0016)}\end{array}$ & $\begin{array}{c}4.048 \\
(0.132 \\
1)\end{array}$ & $\begin{array}{c}0.408 \\
(0.8156)\end{array}$ & 0.197 & 6.293 \\
\hline$\Delta \mathrm{RIR}$ & $\begin{array}{c}2.818 \\
(0.2444)\end{array}$ & $\begin{array}{c}5.538 \\
(0.0627)\end{array}$ & - & $\begin{array}{c}3.940 \\
(0.139 \\
4)\end{array}$ & $\begin{array}{c}5.726 \\
(0.0571)\end{array}$ & -0.006 & -0.073 \\
\hline$\Delta \mathrm{CPI}$ & $\begin{array}{c}6.011 \\
(0.0495) \\
\star \star\end{array}$ & $\begin{array}{c}9.784 \\
(0.0075) \\
\star \star\end{array}$ & $\begin{array}{c}5.624 \\
(0.0601)\end{array}$ & $f_{0}$ & $\begin{array}{c}5.532 \\
(0.0629)\end{array}$ & 0.028 & 3.413 \\
\hline$\Delta \mathrm{M} 2$ & $\begin{array}{c}1.019 \\
(0.6009)\end{array}$ & $\begin{array}{c}8.505 \\
(0.0142) \\
\star \star\end{array}$ & $\begin{array}{c}1.736 \\
(0.4198)\end{array}$ & $\begin{array}{c}2.983 \\
(0.225 \\
0)\end{array}$ & - & $-0.181^{* *}$ & $\underset{*}{2.218^{*}}$ \\
\hline
\end{tabular}

Notes: The $X^{2}$ - statistic tests the joint significance of the lagged values of the independent variables, and the significance of the error correction term(s); $\Delta$ is the first different operator;* denotes statistically significant at 5 percent level.

Figure 1: Summary of Short-Run Causal Linkages

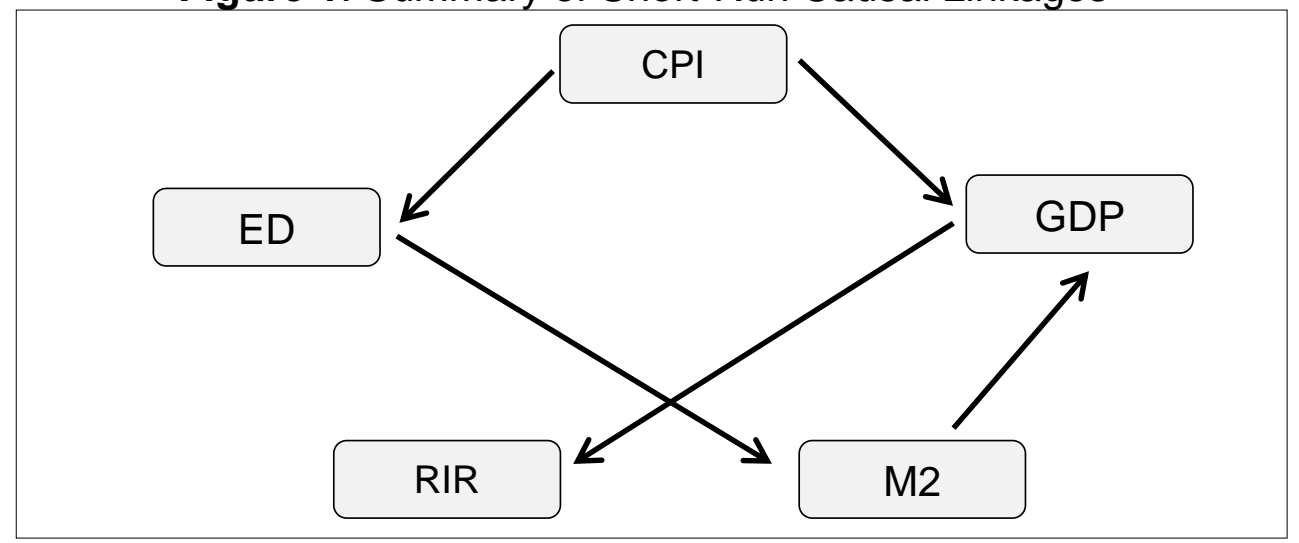

Notes: $\rightarrow$ indicates unidirectional causal relationship

On the causality front, we found several existences of direct causal linkages: (1) CPI is the cause for both ED and GDP (CPI $\rightarrow$ ED and CPI $\rightarrow$ GDP); (2) ED causes M2 (ED $\rightarrow$ M2); (3) GDP causes RIR (GDP $\rightarrow$ RIR); and (4) M2 causes GDP (M2 $\rightarrow$ GDP). Meanwhile, indirectly causality is observed where CPI causes RIR through GDP (CPI $\rightarrow \mathrm{GDP} \rightarrow \mathrm{RIR}$ ). Also, we also observed that CPI causes RIR and it operates through three causing variables: ED, M2 and GDP (CPI $\rightarrow \mathrm{ED} \rightarrow \mathrm{M} 2 \rightarrow \mathrm{GDP} \rightarrow \mathrm{RIR})$. This implies that the five variables are interrelated to each other in the system. All these causality interactions are portrays in Figure 1. 


\subsection{Further Analysis}

In order to strengthen the empirical evidence from causality analysis, the dynamic analysis of the system is examined. We utilized variance decompositions (VDCs) and impulse response functions (IRFs) developed by Sims (1980) to gauge the strength of the causal of the Granger-causal chain or degree of exogeneity amongst the variables beyond the sample period (Masih \& Masih, 2001).Variance decompositions (VDCs), by partitioning the variance of the forecast error of a certain variable into proportions attributable to innovations (or shocks) in each variable in the system including its own, can provide an indication of these relativities (Masih \& Masih, 1999). A variable that is optimally forecast from its own lagged values will have all its forecast error variance accounted for by its own disturbances (Sims, 1982). It is carried out typically based on the moving average (MA) representation of $\operatorname{VAR}(p)$ process with $p$ being the order of the $\mathrm{VAR}^{5}$ :

$$
y_{t}=\sum_{i=0}^{\infty} \Psi_{s} \varepsilon_{t-i}
$$

An alternative of variance decomposition, impulse response functions (IRFs) map out the dynamic response path of a variable due to a one-period standard deviation shock to its determinants. IRF of a dynamic system is its output when presented with a brief signal, called an impulse. Similar to variance decomposition, impulse response function is based on vector moving average $(\infty)$ representation. The matrix $\psi_{s}$ collects the marginal effects of the innovations in the system on to $Y_{t+s} 6$ :

$$
\psi_{s}=\frac{\partial Y_{t+s}}{\partial \varepsilon_{t}^{\prime}} \text { where, } \psi_{i, j, s}=\frac{\partial_{i, t+s}}{\partial_{j t}}
$$

The function that evaluates $\frac{\partial_{i, t+s}}{\partial_{j t}}$ for all $s>0$ is called the impulse response function, which describes the response of $y_{i t+s}$ to a one-time impulse in $y_{j t}$ with all other variables dated $t$ or earlier held constant.

Table 3 presents the decomposition of all the variables in the system. From the results, $\mathrm{RIR}$ is the most exogenous variable with only about 52 percent of its forecast variance

\footnotetext{
5 The $h$-step forecast error for the $y_{t}$ can be written as $y_{t-s}-y_{t}(s)=\sum_{i=0}^{\infty} \psi_{s} \varepsilon_{t+s-i}$, with $y_{t}$ being the optimal $h$-step forecast at period $t$ for $y_{t+s}$. It is straightforward to compute the total forecast error variance of a variable in $y_{t}$ for the $h$-step forecast horizon and the corresponding shares of individual innovations to this variance (Lütkepohl, 2005).

${ }^{6}$ The $\psi_{s}$ is matrix consists of the row $i$, column $j$ which identifies the consequences of one unit increase in the th variable's innovation at date $t\left(\varepsilon_{j t}\right)$ for the value of the th variable at the time $t+s\left(y_{i t+s}\right)$, holding all other innovations at all dates constant.
} 
being explained by the remaining variables in the entire forecast horizon. Apart from that, the VDCs shows that approximately 100 percent of the forecast error variance for CPI can be explained by ED (33 percent), GDP (29 percent), RIR (1 percent) and M2 (36 percent) at the end of the 50 years' time horizon. This indicates that there is a strong direct causality running from $\mathrm{M} 2$ to $\mathrm{CPI}$. This proves that $\mathrm{CPI}$ is the most endogenous variable as it emerged as the recipient of shocks originating from the other macroeconomic variables in the system. It is worth mentioning that even after 50 years' time horizon; most of the variance in ED is largely explained by M2 and following by GDP rather than by other variables in the system. Almost 51 percent of M2 and 26 percent of GDP will explain the ED for Malaysia in the long term, explaining that both M2 and GDP cause ED at the end of the 50 years' time horizon.

As for the IRFs, given a system of five-dimensional variables, 20 possible scenarios of IRFs for each of the variable taken separately, ignoring their own shocks, are constructed. Visual illustrations of IRFs are shown in Figure 2. Most of the graphs are able to settle before 20 years intervals. Meanwhile, RIR and CPI responded negatively to the shock in ED implying the existence of a negative relationship between the two variables to ED. GDP responded positively to the shock in ED before 3 years and remain negative after that while $M 2$ responded positively to the shock in ED, implying positive relationship between M2 and ED.

Table 3: Variance Decompositions (VDCs)

\begin{tabular}{|c|c|c|c|c|c|c|c|}
\hline \multirow{2}{*}{$\begin{array}{l}\text { Percentage } \\
\text { of } \\
\text { variations } \\
\text { in }\end{array}$} & \multicolumn{7}{|c|}{ Due to innovation in: } \\
\hline & $\begin{array}{l}\text { Horizon } \\
\text { (Years) }\end{array}$ & $\Delta \mathrm{ED}$ & $\Delta$ GDP & $\Delta \mathbf{R I R}$ & $\Delta \mathbf{C P I}$ & $\Delta \mathbf{M} 2$ & $\Delta \mathbf{C U}$ \\
\hline \multicolumn{8}{|c|}{ Years relative variance in: $\Delta \mathrm{ED}$} \\
\hline & 1 & 100.000 & 0.000 & 0.000 & 0.000 & 0.000 & 0.000 \\
\hline & 12 & 15.483 & 13.427 & & & & 84.517 \\
\hline & 20 & 12.6 & 21. & & & & \\
\hline & 30 & 14.1 & 24. & 2. & & & 98 \\
\hline & 4 & 15. & 25. & & & & \\
\hline & 50 & 15.550 & & & & & \\
\hline \multicolumn{8}{|c|}{ Years relative variance in: $\triangle$ GDP } \\
\hline & 1 & 15.161 & 84. & & & & \\
\hline & 12 & 24.6 & 16.5 & & 12. & & \\
\hline & 20 & 26.8 & 19.6 & 1.1 & 9.807 & & 80.312 \\
\hline & 30 & 27. & 21. & & & & \\
\hline & 40 & 28.0 & 22.0 & 0.9 & 8. & & 77.992 \\
\hline & 50 & 28.182 & 22.413 & 0.919 & 7.839 & & 77.587 \\
\hline \multicolumn{8}{|c|}{ Years relative variance in: $\Delta R I R$} \\
\hline & 1 & 1.555 & 8.7 & & & & 10.289 \\
\hline & 12 & & 32. & & & & \\
\hline & 20 & & 31.6 & & & & \\
\hline & 30 & 5.3 & 31.7 & 48.105 & 14.640 & 0.2 & 51.895 \\
\hline & 40 & & 31.8 & 47.868 & 14. & & 52.132 \\
\hline & 50 & 5.370 & 31.892 & 47.719 & 14.849 & 0.169 & 52.281 \\
\hline
\end{tabular}


Years relative variance in: $\triangle \mathrm{CPI}$

\begin{tabular}{ccccccc}
1 & 7.772 & 0.460 & 22.046 & 69.722 & 0.000 & 30.278 \\
12 & 32.191 & 23.657 & 6.240 & 2.850 & 35.063 & 97.150 \\
20 & 33.123 & 27.123 & 2.601 & 1.156 & 35.996 & 98.844 \\
30 & 33.206 & 28.391 & 1.474 & 0.915 & 36.014 & 99.085 \\
40 & 33.190 & 28.896 & 1.068 & 0.887 & 35.960 & 99.113 \\
50 & 33.171 & 29.153 & 0.870 & 0.886 & 35.920 & 99.114 \\
\multicolumn{1}{c}{ iance in: } & $\Delta \mathrm{M} 2$ & & & & & \\
1 & 15.900 & 15.154 & 5.942 & 4.666 & 58.338 & 41.662 \\
12 & 40.048 & 14.603 & 4.734 & 11.860 & 28.754 & 71.246 \\
20 & 41.753 & 13.492 & 5.832 & 12.305 & 26.617 & 73.383 \\
30 & 42.978 & 12.218 & 6.949 & 13.005 & 24.849 & 75.151 \\
40 & 43.787 & 11.212 & 7.864 & 13.616 & 23.521 & 76.479 \\
50 & 44.392 & 10.403 & 8.616 & 14.126 & 22.462 & 77.538 \\
\hline
\end{tabular}

Notes: The last column provides the percentage of forecast error variances of each variable explained collectively by the other variables. The columns in italic represent the impact of their own shock.

Figure 2: Impulse Response Function (IRFs)

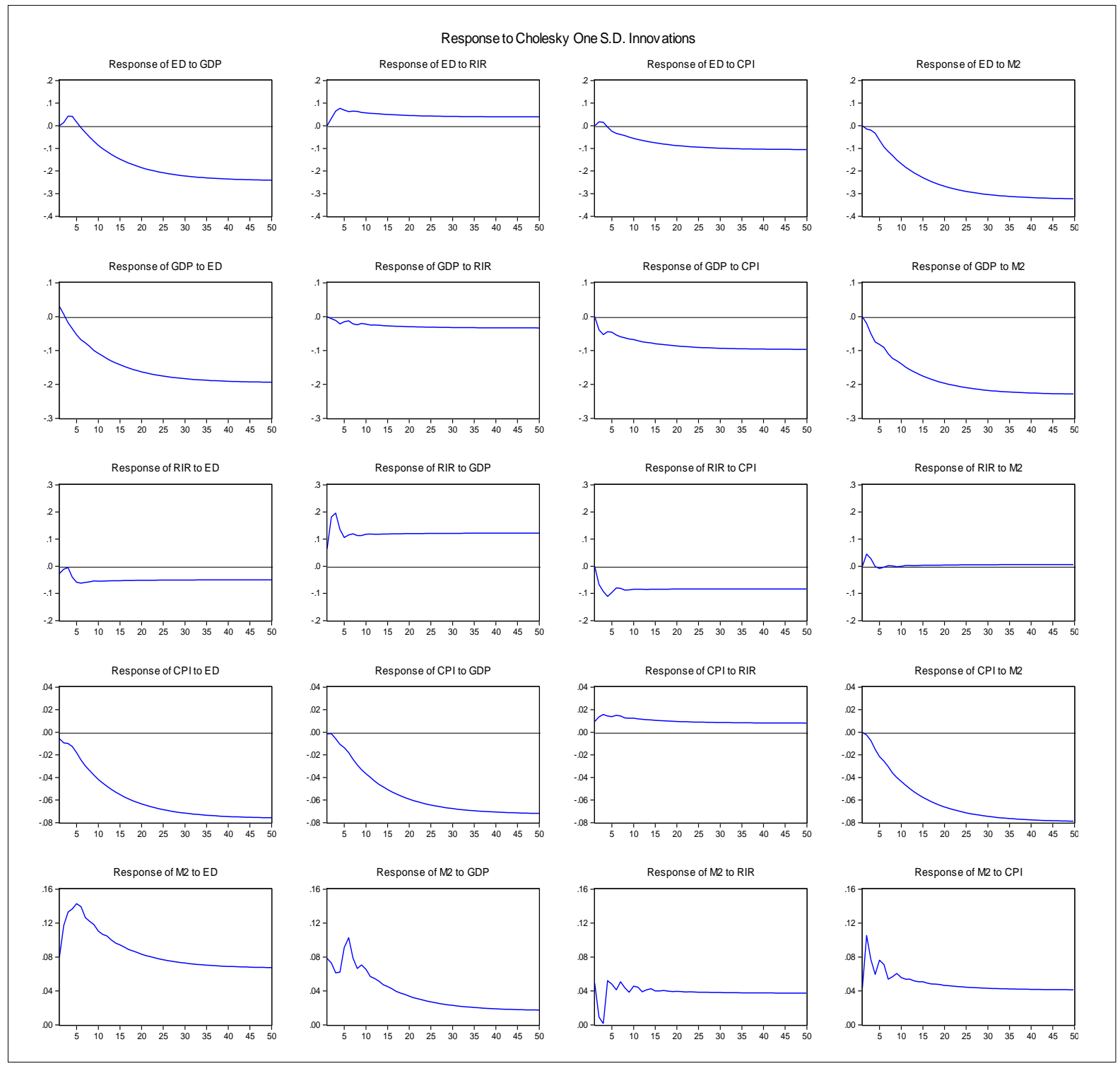




\section{Summary and Conclusion}

The study aims to reinvestigate the relationship between the debt and the macroeconomic indicators in Malaysia from 1970 to 2013. Using the $\mathrm{JJ}$ cointegration test, the results show that the existence of a long run relationship between external debt and the macroeconomic indicators in Malaysia. Focusing on the relationship between the factors contributing to the external debt, the empirical study findings indicate that there is short run connection running from CPI to ED. Other than that, it is noteworthy that there is a connection running indirectly from CPI to RIR through two channels: from CPI to RIR through GDP; and from CPI to RIR through ED, M2 and GDP. Next, the dynamic analysis based on variance decomposition (VDCs) reveals that RIR is the most exogenous variable whilst CPI is the most endogenous variable among the five variables in the system. Moreover, we find that both M2 and GDP is the cause of ED in the long term period beyond the sample.

From a policy perspective, suggestions are that the government of Malaysia should implement an effective external debt management strategy in safeguarding financial and monetary stability. In addition, a comprehensive debt monitoring system which enables early indication of possible risks resulting from the country's debt accumulation to avoid from debt default risk. The introduction of Public Finance Reform Strategic Reform Initiative (SRI) under the Economic Transformation Programme (ETP) in 2010 were part of the proactive action taken that aimed at strengthening the government's finances to ensure stability and sustainability of public funds. Further, Malaysia should develop a debt governance program for pursuit of debt-targeting policies or rules to enhance sound public finance systems which is crucial for Malaysia to achieve solvency in external debt positions in the near future.

\section{Acknowledgement}

The authors are grateful for the valuable comments from two anonymous referees and the editor of this journal on the earlier version of this paper. The authors gratefully acknowledges financial support from Universiti Malaysia Sarawak (UNIMAS) Geran Penyelidikan Khas (Top Down) 03(TD04)/1054/2013(02). Part of the paper was written while the first author was the Visiting Scholar in the Faculty of Economics, University of Cambridge. He thank the Faculty for its hospitality. The usual disclaimer regarding errors and omissions applies.

\section{References}

Ajayi, S. I. (1991). Macroeconomic Approach to External Debt: The Case of Nigeria. AERC Research Paper No. 8.

Awan, A., Asghar, N., \&Rehman, H. U. (2011).The Impact of Exchange Rate, Fiscal Deficit and Terms of Trade on External Debt of Pakistan. Australian Journal of Business and Management Research, 1(3), 10-24. 
Baldacci, E., Gupta, S. and Mulas-Granados, C., (2010) Restoring Debt Sustainability After Crises: Implications for the Fiscal Mix. IMF Working Paper No 232.

Bank Negara Malaysia (2013) Quarterly Bulletin, Third Quarter of 2013.

Cheong K. W., Yong, E. M., Lye, K. H., Tan, K. E., \& Tee, W. S. (2011). Debt, Budget Deficit and Economic Growth of Malaysia. Unpublished thesis, Universiti Tunku Abdul Rahman, Malaysia.

Choong, C. K., Lau, E., Liew, V. K. S., \& Puah, C. H. (2010). Does Debts Foster Economic Growth? The Experience of Malaysia. African Journal of Business Management, 4(8), 1564-1575.

Cline, W., (1984) International Debt: Systemic Risk and Policy Response. Institute of International Economics: Washington, DC.

Cottarelli, C. And Schaechter, A., (2010) Long-Term Trends in Public Finances in the G-7 Economies, SPN/10/13, IMF Staff Position Note.

Daud, S. N. M., Ahmad, A. H., \&Azman-Saini, W. N. W. (2013). Does External Debt Contribute to Malaysia Economic Growth? Ekonomskaistraživanja - Economic Research 26(2), 346-363.

Dickey, D. A., and Fuller, W. A. (1979) Distribution of estimators for autoregressive time series with a unit root, Journal of the American Statistical Association, 74(366), 427-431.

Engle, R. F., \& Granger, C. W. J. (1987). Co-integration and Error Correction: Representation, Estimation and Testing, Econometrica, 55, 251-276.

Johansen, S., and Juselius, K. (1990) Maximum Likelihood Estimation and Inference on Cointegartion with Applications to the Demand for Money, Oxford Bulletin of Economics and Statistics, 52(2), 169-210.

Kwaitkowski, D., Phillips, P. C. B., Schmidt, P., and Shin, Y. (1992) Testing the Null Hypothesis of Stationarity against the Alternative of a Unit Root, Journal of Econometrics, 54, 91-115.

Loganathan, N., Sukemi, M. N., \&Sanusi, N. A. (2010). External Debt and Macroeconomics Performance in Malaysia: Sustainable or Not? Global Economy and Finance Journal, 3(2), 122132.

Loser, C. M. (2004). External Debt Sustainability: Guidelines for Low-and Middle-income Countries. G24 Discussion Paper Series No. 26.

Lütkepohl, H. (2005). New Introduction to Multiple Time Series Analysis. Berlin: Springer Verlag.

Masih, A. M. M., \&Masih, R. (1999). Is a Significant Socio-Economic Structural Change a Pre-Requisite for 'Initial' Fertility Decline in the LDCs? Evidence from Thailand Based on a Multivariate Cointegration/Vector Error Correction Modelling Approach. Journal of Population Economics, $12,463-487$.

Masih, A. M. M., \&Masih, R. (2001). Dynamic Modeling of Stock Market Interdependencies: An Empirical Investigation of Australia and the Asian NICs. Review of Pacific Basin Financial Markets and Policies, 4(2), 235-264.

McFadden, D., Eckaus, R., Feder, G., Hajivassiliou, V., \& O'Connell, S. (1985). Is There Life After Debt? An Econometric Analysis of the Creditworthiness of Developing Countries. In G. Smith \& and J. Cuddington (Eds.), International Debt and the Developing Countries. World Bank: Washington, D.C.

Narayanan, S. (2012) Public Sector Resource Management. In: Malaysia's Development Challenges: Graduating from Middle (eds.) Hal Hill, ThamSiew Yean, Ragayah Haji Mat Zin, Rouledge, pp. $131-154$.

Pyeman, J., Noor, N. H. H.M., Mohamad, W. M. F. W., \& Yahya, A. A. (2014). Factors Affecting External Debt in Malaysia: AN Empirical Investigation. Proceedings of the $1^{\text {st }}$ AAGBS International Conference on Business Management 2014.

Qiu, Y. H. (2010). Debt Crisis and Debt Sustainability in Developing Countries. Unpublished master thesis, University Bielefeld, Germany.

Reinhart, C. M., \&Rogoff, K. S. (2009). This Time is Different: Eight Centuries of Financial Folly. Princeton, NJ: Princeton Press.

Sabahat, Z., \& Butt, M. S. (2008). Impact of Trade Liberalization on External Debt Burden: Econometric Evidence from Pakistan. Munich Personal RePEc Archive (MPRA) Paper No. 9548.

Sims, C. A. (1980). Macroeconomics and Reality. Econometrica, 48, 1-48. 
Sims, C. A. (1982). Policy Analysis with Econometric Models. Brookings Papers on Economic Activity, $13,107-164$

Zeaiter, H. F. (2009) Determinants of Sovereign-Debt Default in Developing Countries, Journal of International Finance and Economics, 9, 131-144.

Zhang, Z.W. and Zhang, W.L. (2011). The road to recovery: Fiscal stimulus, financial sector rehabilitation, and potential risks ahead, Journal of Asian Economics 22, 311-321. 